\title{
The Self-Extinguishing Despot: Millian Democratization
}

\author{
Yvonne Chiu The University of Hong Kong \\ Robert S. Taylor University of California, Davis
}

\begin{abstract}
Although there is no more iconic, stalwart, and eloquent defender of liberty and representative democracy than J. S. Mill, he sometimes endorses nondemocratic forms of governance. This article explains the reasons behind this seeming aberration and shows that Mill actually has complex and nuanced views of the transition from nondemocratic to democratic government, including the comprehensive and parallel material, cultural, institutional, and character reforms that must occur, and the mechanism by which they will be enacted. Namely, an enlightened despot must cultivate democratic virtues such as obedience, industriousness, spirit of nationality, and resistance to tyranny in the population and simultaneously prepare the way for his own demise and secure his own legitimacy by transitioning to the rule of law. This challenges recent scholarship that paints Mill's nondemocratic views as crudely and uncritically imperialist, because it fails to recognize and engage seriously with his sophisticated (if ultimately problematic) theory of individual and institutional development under enlightened colonialism.
\end{abstract}

$\mathrm{T}$ here appears to be an "emerging orthodoxy" among scholars that John Stuart Mill was an uncritical, even morally obtuse apologist for the British Empire and imperialism more generally (Kohn and O’Neill 2006, 220). Mehta, for example, has taken Mill to task for subordinating consent to progress, which enabled him to conveniently overlook the dark, exploitative side of empire, and for allowing individual colonial subjects to be entirely eclipsed by "collective histories" that decided their "differential rights and privileges" (1999, 111-12). On similar grounds, Pitts has condemned Mill for "avoid[ing] the question of whether colonial rule was inherently prone to abuse" $(2005,161)$. Several scholars have begun to call this new orthodoxy into question, however, not by denying Mill's support for an enlightened colonialism-of which there is copious textual evidence-but rather by showing that such support was not based upon racist assumptions about the intrinsic inferiority of subject peoples (Muthu 2003, 279) and was far from uncritical or unconditional. Kohn and O'Neill have shown, for example, that Mill was ambivalent about British rule in the West Indies, as evidenced in part by the Eyre controversy, in which Mill led a parliamentary faction calling for the trial of the colonial governor of
Jamaica for his egregious abuse of power during an uprising there (2006, 213-17; also see Reeves 2007, 377-80).

Strangely, though, what has been wholly missing from this recent debate is any detailed discussion of what we call Mill's theory of "enlightened despotism" and its application to colonial acquisition and administration. This elaborate developmental theory, which explains how "backward" states and their citizens can simultaneously approach liberal-democratic ideals under the guidance of motivated despots, foreign or domestic, animates Mill's discussions of colonialism, yet the participants in this debate have had remarkably little to say about it. Mehta, for example, says that Mill gives a "precisely articulated and specific developmental trajectory" along which enlightened despots must move their societies, but he offers no description of it, even in those parts of his book where he discusses Considerations on Representative Government, its very source (1999, 70-71, 73, 81-82, 103-104). Pitts (2005), by contrast, appears to deny the existence of any such trajectory: she contends that Mill offered us nothing but a rough contrast between barbarian and civilized societies $(133,136-37,139)$, a crude historical story with no analysis of "development within societies" (141), and a focus on individual "cognitive" (vs. ethical) 
development alone (142), claims which are all belied by Considerations, as we shall see. ${ }^{1}$ Both Mehta and Pitts sharply criticize Mill's support for a British brand of enlightened despotism, but no evaluation-much less critique - of Mill's position is possible without an understanding of not only its details but also how it applies within particular colonial contexts. Only by examining these can we hope to pinpoint where exactly his argument goes wrong; Urbinati rightly says that "although this aspect of [Mill's] thought has received little analytical attention, it has been harshly criticized" (2007, 69). A thorough and sympathetic analysis must precede criticism-here, we offer both. ${ }^{2}$

We will first describe the basic features of Millian enlightened despotism, especially as they are initially sketched in On Liberty, and defend Mill against charges of inconsistency. We then move on to the main presentation of these ideas in Considerations, where Mill describes how an enlightened despot might shepherd a society through a multistage process of development, one that involves not merely institutional reform but also the reform of citizens' characters. ${ }^{3}$ We consider here the pressing issue of motivation: why would any despot, foreign or domestic, work patiently towards his own displacement by reforming political institutions and preparing his subjects to take charge of them? As we shall see, Mill's underdeveloped response relies upon both the cun-

${ }^{1}$ Pitts is by no means alone in making these claims. For example,
Mantena cites Pitts and follows her by arguing that Mill's
historical stages "were never carefully elaborated" and were
"rarely linked... with specific social structures, property rela-
tions, or modes of subsistence"; moreover, she contends that "Mill
never specified in great detail what kinds of policies would educate
a subject population towards greater individuality" (2007, 304,
306). Again, all of these claims are belied by Considerations.

${ }^{2}$ Urbinati herself gives a sympathetic reconstruction of Mill's views on despotism in this very context before concluding her piece on a critical note $(2007,74-80,97)$. Moreover, she touches on Mill's developmental theory $(79,95)$ but does not pursue it or its application to particular colonial contexts, as her concern is elsewhere, viz. with the origins of the concept of despotism and its multifarious but related uses in Mill's writings. Also see Tunick (2006) for a similarly sympathetic reconstruction, but one very different from ours and Urbinati's.

${ }^{3}$ Although we are certainly not the first to explore Mill's science of character formation (which he calls "Ethology" in his System of Logic), we are the first to do so in the specific context of his enlightened despotism. Ball (2000), for example, treats Mill's major works as "case studies in applied ethology"; when he turns to Considerations, however, he focuses wholly on Mill's critique of despotism there and on his related claim that "active characters" are essential conditions of democratic government, whereas we examine Mill's qualified defense of despotism in this same work as a means to character development in undeveloped societies, thereby complementing Ball's analysis (25, 40-43). Also see the seminal work on Mill and character formation by Himmelfarb (1974), especially Chapters 3, 5, and 10. ning of history (with echoes of Kant) and a faith in disinterested technocratic elites. Finally, we examine in greater detail how Mill applies his theory of enlightened colonialism to the most important of the British dependencies and the one he discusses at greatest length, India, to see what this reveals about Mill's theory and its limits. The point of our (re)examination of the relevant writings here is not a defense of Mill's enlightened despotism/colonialism per se, but a defense of its coherence, its depth (as grounded in a full theory of institutional and character development), and its moral seriousness and self-critical quality, which serves as a necessary precursor to an informed critique.

\section{Millian Enlightened Despotism: Basic Features}

Immediately after stating his doctrine of liberty in $\mathrm{On}$ Liberty, Mill qualifies it by noting that it applies neither to children nor to "backward states of society in which the race itself may be considered as in its nonage" (OL 14). "Despotism" over such "barbarians" may be warranted, Mill says, "provided the end be their improvement, and the means justified by actually effecting that end" (OL 14-15; cf. CRG 453: "vigorous despotism"). Mill has in mind here the despotism of Akbar, Charlemagne, and Peter the Great, all of whom he suggests were filled with "the spirit of improvement" (OL 14; cf. CRG 26465). He also emphasizes, however, that such despotism must be self-extinguishing to be legitimate: once mankind is able to be improved by "conviction and persuasion" and "free and equal discussion," the doctrine of liberty applies in full (OL 15). The strong paternalism of this passage is explicit and unmistakable: barbarians are like children, and (good) despots are like parents, whose rule over their charges is justified and eventually terminated by their wards' achievement of maturity and independence. ${ }^{5}$

\footnotetext{
${ }^{4} \mathrm{We}$ will use the following notations for Mill's works: $\mathbf{C}=$ "Civilization" (Mill 1977, 119-147); NI = "A Few Words on Non-Intervention" (Mill 1984, 111-24); OL = On Liberty (Mill 1991, 1-128); U = Utilitarianism (Mill 1991, 129-202); CRG = Considerations on Representative Government (Mill 1991, 203468); SW = The Subjection of Women (Mill 1991, 469-582); and PPE $=$ Principles of Political Economy (Mill 1909). Mill defines "barbarism" as a dispersed population with a hunter/gatherer economy and an anarchic lack of cooperation (C 120).

${ }^{5}$ As Mehta points out, Mill believes that whereas in advanced conditions libertarian norms best advance utility, in "backward" conditions, "alternative norms" like enlightened despotism are more effective (99, 102-103; cf. SW 517-18).
} 
This endorsement of enlightened despotism, however qualified it may be in both structure and application, will strike many readers as grossly inconsistent with Mill's other discussions of despotism, which are usually sharply critical of it. Such inconsistency is only apparent, however. For example, when we turn to Mill's discussion of the Mormon institution of polygamy and of the "unquenchable animosity" it sparks in most Christians, we find Mill condemning interference with the Mormons as a kind of "tyranny," asserting that "I am not aware that any community has a right to force another to be civilized" (OL 102). This appears to be in tension with earlier statements, but recall that enlightened despotism was only appropriate where the subject people were incapable of improvement through "conviction and persuasion" and "free and equal discussion" (OL 15). Mill clearly believed that the Mormons were capable of being improved in this way, however, as evidenced by his comment that their critics should send "missionaries" to persuade them to abandon their polygamous practices instead of proposing a "civilizade" against them (OL 102-103). ${ }^{6}$ The same holds true, and even more strongly, with respect to the marital "law of despotism" that Mill so vigorously critiqued in The Subjection of Women (SW 501). Not only were women susceptible of improvement through persuasion and discussion, he argued, but also the sort of despotism practiced within marriage distorted and degraded women's capacities - and men's as well-instead of enhancing them (SW 486-87, 493-94, 509-10, 520). ${ }^{7}$ Consistent with his earlier statements in On Liberty, despotism can only be justified when its end is improvement, its means are fitted to that end, and its beneficiaries cannot be helped by other, less coercive means, such as persuasion. Neither Mormons nor women as a class need such despotism; as Mill plainly states, only children and "barbarians" require it. ${ }^{8}$

${ }^{6}$ To be clear, Mill viewed polygamy as a "direct infraction" of his principle of liberty but thought that so long as the Mormons did not force their practice on others or prevent women from escaping it via migration, they should remain unmolested (OL 102). This is consistent with his related opinion that "mismanagement" or even "great rudeness and imperfection in the details of public affairs" cannot by itself justify interference across communities (SW 577).

${ }^{7}$ Mill's belief that despotism, especially marital despotism, is mutually degrading for despot and subject was shared by Montesquieu, with whose work Mill was familiar: see both Montesquieu's portrayal of Usbek in The Persian Letters (1964) and his broader treatment of the topic in The Spirit of the Laws (1989).

${ }^{8}$ Fuchs (2001) defends Mill against charges of inconsistency for his qualified endorsement of liberal paternalism.
The passage of On Liberty cited above consists of less than one paragraph, however, and its telegraphic quality leaves many important questions unanswered. For example, what should an enlightened despot "improve" about his subjects? What techniques should he use to do so? Why would these improvements eventually lead to their maturity and selfgovernment? Lastly, what would motivate a despot to do any of these things? Fortunately, Mill sketches answers to all of these questions in Considerations on Representative Government.

\section{Millian Enlightened Despotism: Developmental Trajectories, Despotic Motivations}

In Considerations, Mill speaks of societies being at different "stage[s] of advancement," and what a society at the lowest level of advancement (a state of "fighting and rapine" and "savage independence") needs is a despot, an "absolute ruler," who will teach it two virtues essential to civilized life: obedience and patient industry (CRG 231-32). The former virtue, bringing peace in its wake, is necessary for the development of the latter, without which "neither can the mind be disciplined into the habits required by a civilized society, nor the material world prepared to receive it"; these twin virtues are of such weight that even "personal slavery" might be justified as an encouragement to them both, at least at this early stage of social advancement (CRG 232; cf. C 123-24 and NI 119 [“... break their spirit..."]).

Mill is quick to recognize, however, that a people of slaves under an absolute ruler, no matter how enlightened he may be, will never be transformed into a self-governing people unless they are led to acquire further virtues. To usher his people on to "the next necessary step in social progress," such a ruler must transform his own rule, changing it from "a government of will to one of law" (CRG 233). ${ }^{9}$ The ruler, in other words, must develop in his people "the capacity to act on general instructions"; he must maintain "a general superintendence over all the operations of society, so as to keep before each the sense of a present force sufficient to compel his obedience to the rule laid down, but which, owing to the impossibility of descending to regulate all the minutiae of

\footnotetext{
${ }^{9}$ As Miller notes, "for Mill personally, the main issue at stake [in the Eyre controversy] was 'whether the British dependencies... were to be under the government of law, or of military license"' (2005, 159-60, 164).
} 
industry and life, necessarily leaves and induces individuals to do much of themselves" (CRG 233-34).

Mill is unclear about how this increased discretion for the governed is to be introduced. His one concrete example in the text-a "St. Simonian form of socialism," such as that practiced by the Jesuits in Paraguay (CRG 233-34)—does not seem particularly promising, given his critical discussion of this system in Principles of Political Economy. Although socialism of this variety, being noncommunistic, would "proportion remuneration to labor" and thus avoid communism's disincentive to work, it would also require a degree of "genius and virtue" on the part of those who assigned workers to their stations (on the basis of capacity and merit) that Mill finds "almost too chimerical to be reasoned against" (PPE 211-13).

Are there alternative examples in Mill's writings that would serve his purposes better? One that might fit the bill is so-called "peasant proprietorship," discussed extensively in Political Economy and sharply contrasted with slavery (PPE 256-301). Under peasant proprietorship, "the whole produce [of the land] belongs to a single owner," i.e., the peasant himself; alternatively, the peasant might pay a fixed rent to either the landlord or the government (in which case it is equivalent to a land tax) (PPE 256-57, 333). So long as the rent is fixed, any produce beyond the rent accrues to the peasant, providing a strong incentive for labor. Consequently, the peasant may safely be given a great deal of discretion with respect to the disposition of his own labor and property. The ruler's managerial role is reduced to the general one of distributing and enforcing property rights in land and regulating rents. The purpose of such a system, as Mill explains, is "more complete security of property; moderate taxes, and freedom from arbitrary exaction under the name of taxes; a more permanent and more advantageous tenure of land, securing to the cultivator as far as possible the undivided benefits of ... industry, skill, and economy" (PPE 189). These desiderata are achieved by securing long, preferably perpetual land tenure for peasants and by fixing rents and land taxes for the length of that tenure, or at minimum limiting their increase by custom or law (PPE 257, 283, 333).

These ideas could have been applied to the British colony of India. The Indian class whose situation was most similar to that of the peasant proprietors were the "ryots," or peasant farmers. As Mill explains, they are "not regarded as tenants at will, nor even as tenants by virtue of a lease [but rather] are thought entitled to retain their land, as long as they pay the customary rents" (PPE 243-44). These rents, though, had a tendency to increase over time (in real if not nominal terms) due to the "fiscal rapacity... of the great landholder, the State," or the "illegal extortions" of local administrators, so that the fixed rents of peasant proprietorship were never achieved; as a result, "the anomaly arose of a fixity of tenure in the peasantfarmer, co-existing with an arbitrary power of increasing the rent" (PPE 244, 325).

The reason that a move from slavery or serfdom to peasant proprietorship would be "the next necessary step in social progress" is that such a system not only encourages industry (which slavery does, after all) but also promotes the development of greater virtues, such as intelligence, prudence, and selfcontrol (PPE 285-87). As Mill cogently argues, "mental faculties will be most developed where they are most exercised; and what gives more exercise to them than the having a multitude of interests, none of which can be neglected, and which can be provided for only by varied efforts of will and intelligence?" (PPE 285; cf. CRG 253-56). Peasant proprietors are beset with so many concerns and anxieties that their minds are constantly churning, unlike the dull, stupefied minds of slaves. ${ }^{10}$ Moreover, because their livelihood depends so strongly upon their own decisions, they become very careful and temperate; as Mill observes, "they deny themselves reasonable indulgences, and live wretchedly in order to economize" (PPE 287).

In fact, Mill contends that "no other existing state of agricultural economy has so beneficial an effect on the industry, the intelligence, the frugality, and prudence of the population" (PPE 300). Because any surplus over rent and taxes accrues to the peasant himself, he has a strong incentive not merely to labor but also to plan, save, and invest, all of which encourage the development of the aforementioned virtues. Peasant proprietorship is thus "an instrument of popular education," one so effective that its lesson is perhaps learned too well: "if there is a moral inconvenience attached to [this system], it is the danger of their being too careful of their pecuniary

\footnotetext{
${ }^{10}$ For this reason, Mill advocates the abolition of cottier tenancy in Ireland, in which "the conditions of the [tenancy] contract, especially the amount of rent, are determined not by custom but by competition" (PPE 318). Such tenancy leads to rents so high, and therefore remuneration of labor so low, that Mill remarks despairingly, "What can a tenant gain by any amount of industry or prudence, and what lose by any recklessness?... A situation more devoid of motives to either labor or self-command, imagination itself cannot conceive. The inducements of free human beings are taken away, and those of a slave not substituted... What race would not be indolent and insouciant when things are so arranged, that they derive no advantage from forethought or exertion?" (PPE 323-24).
} 
concerns.... But some excess in this direction is ... a cheap price to pay for the inestimable worth of the virtue of self-dependence" (PPE 287). ${ }^{11}$

Unlike the virtues of obedience and patient industry, which are necessary conditions for any form of civilization, the bourgeois virtues of a calculating intelligence, prudence, and self-control are necessary conditions for only certain kinds of civilization, including the democratic one. One of the greatest threats to democratic self-government is the demagogue, who exploits the fears and passions of the masses in order to procure political power and achieve dominance. Demagoguery maintains the democratic form (by way of a plebiscitary politics) but destroys its essence, which is deliberation and compromise. Those given democratic freedoms and responsibilities but not yet accustomed to the exercise of the knowledge, understanding, self-restraint, and respect they require will fall sway to demagogues or their autocratic equivalents, something Mill would have seen in his own lifetime and in his extensive study of ancient Greek philosophy and history. However, the bourgeois virtues of intelligence, prudence, and self-control, if possessed by most of the demos, deny the demagogue his foothold: citizens who customarily consider the long-term consequences of decisions, act only with caution and forethought, and keep their own impulsive desires in check will be unmoved by his bullying rhetoric or by farcical aquatic ceremonies. Thus, the virtues acquired by the peasant proprietor are among those required of a democratic citizen. ${ }^{12}$

This transition from a government of will to a government of law, important though it is in grooming citizens for self-government, is not the final

\footnotetext{
${ }^{11}$ Mill also defends peasant proprietorship on Georgist grounds, arguing that "the land of every country ... belongs to the people of that country ... With regard to the land itself, the paramount consideration is, by what mode of appropriation and of cultivation it can be made most useful to the collective body of its inhabitants" (PPE 331). Although this mode will usually be peasant proprietorship, Mill admits that "large farms, cultivated by large capital, and owned by persons of the best education which the country can give, persons qualified by instruction to appreciate scientific discoveries, and able to bear the delay and risk of costly experiments, are an important part of a good agricultural system" (PPE 334). Barring this telling exception for an educated agricultural elite, however, Mill's defense of peasant proprietorship is unstinting.

${ }^{12}$ Sullivan (1983, 615-17) and Kurfirst (1996, 80-83) have also described peasant proprietors as proto-democratic citizens. Sullivan sees the virtues of "effort, foresight, and prudence" acquired by such smallholders as preconditions of "liberal cultural and political institutions" (615). Kurfirst similarly links small-scale property ownership to both "intellectual and moral development" and "human freedom and self-government" (82).
}

preparation. As Mill argues, an enlightened despot must now encourage additional democratic virtues among his subjects and equip them with institutions that will eventually serve as the organs of collective self-rule (CRG 260-66). The first of these virtues is, paradoxically, a willingness to resist tyranny (CRG 261-62). ${ }^{13}$ This virtue serves as a needed counterpoint to the virtue of obedience: democratic citizens must be as resistant to usurpers and to arbitrary rule as they are conformable to lawful governance; the tension between these two virtues is a healthy one for a democracy. But by inculcating such a virtue, would the enlightened despot not be undermining (in a very immediate sense) his own rule? Not if the object of resistance were local tyrants. Mill suggests, with substantial historical support, that rulers can often consolidate and strengthen their own rule by aligning themselves with their subjects in struggles against local oppression by, for example, feudal lords or even landlords more generally, as suggested by his discussion of peasant proprietors; as Mill notes, "obedience to a distant monarch is liberty itself compared with the dominion of the lord of the neighboring castle" (CRG 261). ${ }^{14}$

This resistance to local oppression is closely related to the second of these virtues: that of a certain spirit of nationality, ${ }^{15}$ which serves as an antidote to the "inveterate spirit of locality" (CRG 262; also see CRG 427-34). By being pressed into the service of a central authority, subjects become familiarized with the "large interests common to a considerable geographical extent," an experience that extends their knowledge beyond their local village or market town and without which there cannot be "any largeness either to their conceptions or their sentiments" (CRG 254, 263). Only a subject whose mind has been expanded in this way is fit for democratic citizenship, which requires deliberation and decision making about matters of more than parochial interest.

But as Mill notes, one of the most effective ways to encourage familiarity with these larger interests is for a ruler to invite his subjects (or, more precisely,

\footnotetext{
${ }^{13} \mathrm{Few}$ in Mill's time exemplified this virtue better than Giuseppe Mazzini, republican revolutionary and advocate of Italian unification. Mill, who knew him during the early years of his exile in London, had the "highest admiration" for him and said that "to him is mainly owing the unity \& freedom of Italy" (Mill 1972, 1759).

${ }^{14}$ This strategy can be used for good or for ill-an example of the
latter being present-day China.

${ }^{15}$ For an excellent discussion of this sentiment and how it differs from common contemporary understandings of nationalism, see Varouxakis (2002).
} 
their representatives) "into council" with him, thus creating "representative institutions without representative government" (CRG 263). The "political education" these representatives receive by acting as advisors is then "carried home," so to speak, to their constituents, who themselves deliberate on such matters when they choose (or at least petition) their representatives; moreover, as Mill explains, a "tradition is kept up of government by general consent," one that might eventually be given greater significance through constitutional codification (CRG 263-64; cf. C 127). Were this to occur, the transition to a form of democratic self-government would be nearly complete. ${ }^{16}$

We now have answers to the first three questions posed at the end of the previous section: to wit, what should an enlightened despot improve about his subjects, how should he do so, and why would these improvements make eventual self-government possible? The incremental transition to democracy involves a step-by-step process of institutional reform (from slavery and serfdom to peasant proprietorship to political centralization and finally representative institutions) that induces a parallel process of character reform (i.e., the accumulation of a complementary set of citizen virtues: obedience and patient industry; intelligence, prudence, and self-control; a willingness to resist tyranny; and a spirit of nationality). At the close of this process, the enlightened despot has managed to create not only a set of democratic institutions but also a citizenry virtuous enough to run them. Contra Pitts, Mill has offered us a nuanced, multistage account of the developmental trajectory from barbarism to democratic civilization, one that takes place within (rather than across) societies and requires both intellectual and moral improvement of the citizenry (cf. Pitts 2005, 133, 136-37, 139, 141-42).

This leaves the fourth question as yet unanswered: what would motivate a despot to do any of these things? On this point Mill is less forthcoming. To be an enlightened despot, a ruler must have both the ability and the will, and Mill believes that a sufficiently able ruler (i.e., "a monarch of extraordinary genius") will be a "rare accident" (CRG 264). Even assuming that such a genius (or better, given the scale of the tasks involved, a succession of geniuses) might achieve absolute political power, why would he (or they) set in motion the processes of institutional and character reform that would ultimately undermine autocratic rule? Mill hints at one possible answer during his discussion of the

\footnotetext{
${ }^{16}$ Mill emphasized that this must be self-government by an entire population, not just by a tiny minority of whites (with blacks kept disenfranchised), as was unfortunately the case with Jamaican home rule (Miller 2005, 168-69).
}

political history of the Jewish people (CRG 235-36). He mentions there the conflict between the Jewish kings and priests and the "Order of Prophets," whose divinely inspired challenges to the authority of absolute monarchy and religious hierarchy prompted both reinterpretation and reform of the national religion, and he contends that such an "antagonism of influences... is the only real security for continued progress" (CRG 235; cf. NI 119). Mill appears to suggest here that a self-interested struggle between competing political authorities can generate a kind of progress that is unintended by the competing parties. The earlier example of the centralizing monarch may also fit this model: by encouraging resistance to local tyranny and by setting up representative institutions (perhaps as a partial inducement to such resistance or as a means of obtaining revenue [North 1990, 113]), a monarch may defeat his competitors only by politically empowering his own subjects-a concession that will likely come back to haunt him or his heirs.

Mill was broadly familiar with Kant's progressive historical narrative, and his scattered thoughts on the motivation of enlightened despots parallel Kant's, though the latter's are much more fully developed (Mill 1985, 258-59). Kant also believed that the transition to representative democracy would take place under the enlightened rule of an absolute monarch, one who would lead his subjects from a state of minority (i.e., the inability to think for themselves without the guidance of another) to complete intellectual and political self-government. The monarch would discharge this task by maintaining public order, protecting civil liberties including freedom of the press, promoting (or at least not hampering) public education, and steadily ceding legislative power to representative institutions on matters of war, taxation, etc. Most importantly for our purposes, he would be driven to take these actions - which are wholly contrary to his longrun interests-by the exigencies of geopolitical competition: in order to strengthen his society for such competition and secure the financing needed for military campaigns, he would slowly have to enlighten and empower his own people via religious, socio-economic, and political reforms. Though each step in this process would prove in the short-run interest of the monarch, it would lead to his political disempowerment in the long run, turning him into a limited, constitutional monarch constrained by a democratic legislature. ${ }^{17}$ Kant, in short, relied upon an international analogue of the

\footnotetext{
${ }^{17}$ For a detailed analysis of Kant's theory of democratic transitions, see Taylor (2006). For a superb discussion of these characteristics of enlightened despotism in the context of Mill's own theory, see Holmes (2007, 328-30, 336-37).
} 
salutary domestic political competition later identified by Mill. The two of them seem to be saying the following: although we might hope for Catherine, Frederick, and Peter the Greats to do the right thing for the right reasons, the motivation provided by competition, be it domestic or international, should remedy any deficits in political virtue.

Even granting our interpretation of Mill's "antagonism of influences" argument, he does not seem particularly optimistic about the possibility of enlightened despotism: he clearly doubts the capacities of native elites, and he says with artful understatement that "the mere position of the rulers does not... of itself invest them with interests and tendencies operating in the beneficial direction" (CRG 264). At this point, however, Mill himself takes an international turn, introducing his deus ex machinaan imperialism of the civilized over the uncivilized:

From the general weaknesses of the people or of the state of civilization, the One [monarch] and his counselors, or the Few [aristocrats], are not likely to be habitually exempt, except in the case of their being foreigners, belonging to a superior people or a more advanced state of society. Then, indeed, rulers may be, to almost any extent, superior in civilization to those over whom they rule; and subjection to a foreign government of this description, notwithstanding its inevitable evils, is often of the greatest advantage to a people, carrying them rapidly through several stages of progress, and clearing away obstacles to improvement which might have lasted indefinitely if the subject population had been left unassisted to its native tendencies and chances. (CRG 264 [emphasis added]; cf. CRG 453-54)

Such an imperialism solves (or at least alleviates) two problems: first, it explains how a ruler can come to have the expertise necessary to shepherd a whole society "rapidly through several stages of progress"; second, it provides a security of tenure unavailable to "barbarous despotisms," thus allowing time for the required improvements to take place (CRG 454).

Even assuming these advantages, however, his proposed solution still leaves our familiar problem unsolved: motivation. A foreign power would appear, if anything, still less motivated than a native despot to carry a subject people to independence and democratic self-government: a native despot might at least share a common culture, language, religion, etc., with his subjects, which could foster concern for their welfare; such a connection would be missing for the foreign ruler. Mill offers little help on this point. When discussing settler colonies from civilized nations, he suggests that retaining ties with them may promote free trade and also increase the colonizer's prestige among other powers, reasons that would presumably apply to uncivilized dependencies as well, especially given their usefulness as markets for capital and suppliers of grain (CRG 451; PPE 189-90, 19397; Sullivan 1983, 607-13). ${ }^{18}$ It is unclear, however, whether these reasons would translate into a desire to carry out an "enlightened imperialism"; although establishing the rule of law and financing infrastructure in these dependencies would facilitate such economic activity, these would merely be the first of many required steps towards colonial self-government.

At moments such as this one, Mill has an unfortunate tendency to fall back on whatever political virtue foreign rulers happen to possess: he warns that if they fail to discharge their duty to advance civilization in dependent states they are "guilty of a dereliction of the highest moral trust which can devolve upon a nation; and if they do not even aim at it, they are selfish usurpers"; he apparently hopes that guilt will promote progressive policies whenever self-interest fails to do so (CRG 454). As noted earlier, Mill is certainly aware of the possibility of abuse and even exploitation in colonial relations (see, for example, Kohn and O'Neill 2006, 213-17, on the Governor Eyre episode in Jamaica). His solution to such threats, though, is to shift colonial administration from the people's representatives to an impartial technocratic elite, which is how he views officials from his own East India Company (CRG 454-67). Mill explains here why this delegation of governing authority will improve on direct administration by Parliament:

A delegated administration has always this advantage over a direct one, that it has, at all events, no duty to perform except to the governed. It has no interests to consider except theirs. Its own power of deriving profit from misgovernment may be reduced... to a singularly small amount: and it can be kept entirely clear of bias from the individual or class interests of anyone else. (CRG 461-62)

Mill makes a persuasive case that such delegation will be better than direct administration, owing to the relative expertise of professional administrators, their commensurately greater knowledge of native cultures and concerns, and their insulation from domestic political pressures. What he does not do is explain why the interests of these administrators will track the interests of colonial subjects better than some native alternative. Even if we assume, as Mill does, that expertise and security of tenure for (delegated)

\footnotetext{
${ }^{18}$ For a brief discussion of character development through the disinterested bureaucratic rule of settler colonies (as distinct from the uncivilized dependencies that are our focus), see Bell (2010, especially $42-43,46$ ).
} 
foreign rule by a civilized nation will be superior to those of a home-grown despotism, it does not follow that a superior "identity of interest with the governed" will obtain (CRG 461).

What is surprising is how alive Mill is to this problem in other contexts, especially in The Subjection of Women. He says there that "it would be tiresome to repeat the commonplaces about the unfitness of men in general for power" and that "the relation of superiors to dependants is the nursery of those vices of character, which, wherever else they exist, are an overflowing from that source" (SW 509-10). If the arbitrary rule of husbands over wives, where there is frequently at least some tie of affection or common interest between governor and governed, is such a cause of concern for Mill, why would arbitrary colonial rule in the complete absence of either not be even more worrisome to him? Mill's equation of "backward states of society" with children, which we began the previous section by emphasizing, has as its complement another, even more troubling equation: of colonial administrators with parents. However, there are fundamental differences between improving yourself and improving others, and between improving intimate others (e.g., children) and alien others (e.g., colonial dependants)—differences generated by dissimilarities across these contexts in the knowledge, motivation, and sympathy of the purported improver. Does Mill ever recognize these dissimilarities and, if so, how does he deal with them? To answer this question and related ones, we must return to his assessments of colonialism in practice.

\section{Millian Enlightened Despotism: A Detailed Application to India}

The true nature and limits of Millian enlightened despotism become clearer by examining Mill's application of it, especially two interrelated aspects, to a particular colonial context. First, we have discussed the developmental stage of peasant proprietorship as applied to India-its definition and its relevance in the Indian context-and we now turn to its role in the British reform efforts there. Second, we also examine Mill's complex, conflicted attitude regarding the capacity and motivation (or lack thereof) of India's colonial administrators.

Mill says that English colonial administrators "were, at an early period, struck with the importance of putting an end to this arbitrary character of the land-revenue, and imposing a fixed limit to the government demand" (PPE 325); that is, they had every intention of acting like good Millian enlightened despots, advancing the economic interests and personal development of their colonial wards by means of institutional reform. Their initial efforts in this direction, however, were nothing short of disastrous. Upon surveying the Indian social landscape, they misidentified the "zemindars," a hereditary class of rent collectors for the sovereign, as "the proprietors of the soil, the landed nobility and gentry of India" (PPE 325-26). After empowering them as such, "they flattered themselves that they had created ... English landlords, and it proved that they had only erected Irish ones. The new landed aristocracy disappointed every expectation built upon them. They did nothing for the improvement of their estates, but everything for their own ruin" (PPE 327). The British government had thus saddled itself and the ryots with a parasitic landlord class throughout the land of Bengal. Mill's explanation for this spectacular failure of sociological nous is revealing and bodes ill for his hopes for an enlightened colonialism: he says of the English government in India that "its mistakes arose from the inability of ordinary minds to imagine a state of social relations fundamentally different from those with which they are practically familiar" (PPE 325) - the dissimilarity in contexts explains the failure of understanding, in short, but it also calls into question the capacity of colonial administrators to carry their wards "rapidly through several stages of progress" (CRG 264).

British administration of later colonial acquisitions in India improved, but only gradually and incompletely. The colonial governors began collecting rents directly, but instead of offering a "perpetuity of tenure at a fixed rent," they offered longish leases at rents varying by their own assessments of a ryot's ability to pay. In 1871 , Mill reports that a "resolution has been adopted by the Indian government of converting the long leases of the northern provinces into perpetual tenures at fixed rents," thus belatedly achieving in only a part of India what Mill's developmental theory prescribes as an essential step in individual and societal development (PPE 327-28, 332).

In the course of showing how Mill thought one stage of his developmental theory should have been applied in India-but was not, or only belatedly and partially-we have already begun to identify another feature of Mill's attitude towards enlightened colonialism: doubts about the capacity (with respect to both expertise and security of tenure) and motivation of British colonial administrators. In fact, Mill's view 
of British colonialism in India has a self-critical quality that has been insufficiently noticed. With regard to (in)capacity, we have already seen Mill's highly critical views regarding the bungled, haphazard transition to peasant proprietorship under British colonial rule; but his denigration of such rule extends back even further in time, to the initial extension of imperial power to India. In subduing the native states of India, the British had to substitute their military force for that of the princes whom they had disarmed. Mill describes the unintended consequences as follows:

We engaged that this force should fulfill the purposes of a force, by defending the prince against all foreign and internal enemies. But being thus assured of the protection of a civilized power, and freed from the fear of internal rebellion or foreign conquest, the only checks which either restrain the passions or keep any vigour in the character of an Asiatic despot, the native Governments either became so oppressive and extortionate as to desolate the country, or fell into such a state of nerveless imbecility, that every one, subject to their own will, who had not the means of defending himself by his own armed followers, was the prey of anybody who had a band of ruffians in his pay.... During this period of half a century, England was morally accountable for a mixture of tyranny and anarchy, the picture of which, by men who knew it well, is appalling to all who read it. (NI 119-20 [emphasis added]; also see Miller 2005, 170)

The British state eventually abrogated its treaties with the native princes and assumed its duties of colonial government more directly, but, as Mill indicates, it was an exceedingly slow learner. ${ }^{19}$

Mill also worries about the nonidentity of interest between colonial administrators and their wards (CRG 461). Such identity might be expected to grow over time as governors learned about and came to sympathize with those whom they governed, but Mill remains skeptical of this possibility: as he says, "foreigners do not feel with the people. They cannot judge, by the light in which a thing appears to their own minds, or the manner in which it affects their feelings, how it will affect the feelings or appear to the minds of the subject population" (CRG 455). As a result, colonial dependents will remain alien, removing or weakening an important source of motivation for enlightened colonial rule, viz. sympathy.

Despite all of this, Mill still retains a remarkable faith in the capacity and motivation of a specifically English elite. England, he maintains, has "attained to

\footnotetext{
${ }^{19}$ Mill is even more harshly critical of the history of British rule in Ireland (see, e.g., PPE 329-30 and CRG 433).
}

more of conscience and moral principle in its dealings with foreigners, than any other great nation seems either to conceive as possible, or recognize as desirable," and it has picked its "best men," in terms of "qualifications [both] moral and intellectual," to carry out these tasks, especially that of colonial administration (CRG 451, 456, 463-64; cf. NI 11112). This trust in English elites is on display both here and in his defense of plural voting, and in both cases we discover Mill conflating-whether consciously or unconsciously-these two types of qualification. In the midst of a discussion of accountability for colonial administrators, Mill reminds us that "opinions may be weighed as well as counted, and the approbation or disapprobation of one person well versed in the subject may outweigh that of thousands who know nothing about it"; this belief motivates his argument for giving more votes to the "higher moral or intellectual being" as well (CRG 334, 460). Interestingly, in both of these cases, plural voting and colonialism, Mill gradually lets drop his talk of moral superiority, focuses on mental superiority alone, and ultimately proposes "general" and "competitive" exams as the means of allocating votes and colonial posts, respectively-all while leaving one with the distinct impression that moral qualifications are still being selected for (CRG 336, 464; see, e.g., CRG 340, where his phrasing reverts to "moral and intellectual excellence"). This appears to be mere wishful thinking by Mill: if intellectual and moral virtues are strongly positively correlated, selecting for the former via competitive examinations will automatically select for the latter, and the "best men" in all relevant senses will thereby be empowered-but why would these virtues be so correlated? Ensuring the disinterestedness of those entrusted with nearly unfettered power over colonial dependents will not be so simple.

In Mill's defense, he would likely emphasize the unavoidably second-best quality of the colonial enterprise. Perhaps superior capacity (at least relative to native elites) can substitute for a possibly inferior motivation or disinterestedness; as he sadly notes, "real good government [foreign or domestic] is not compatible with the conditions of the [Indian] case. There is but a choice of imperfections" (CRG 461). $\mathrm{He}$ would also urge us not to romanticize native despotisms but rather to compare real with real: British colonialism with native despotism as actually practiced. Throughout his writings, Mill is frank not only about the failures of British colonialism but also about the ugliness of what it replaced: "military and fiscal rapacity," "illegal extortions," and other abuses of power by tyrannical princes and privileged 
landholders alike; inhumane cultural practices (e.g., suttee and "other modes of self-immolation"); etc. (PPE 122, 244, 325; CRG 460; Mill 1990, 27, 123).

Moreover, Mill believes that by selecting the right form of colonial government, one can minimize the inevitable motivational deficits of its functionaries and maximize its capacity (in terms of expertise and security of tenure). As he describes it, "the problem is, so to construct the governing body that, under the difficulties of the position, it shall have as much interest as possible in good government, and as little in bad. Now these conditions are best found in ... a delegated administration," in this case his own East India Company (CRG 461). He says that "its own power of deriving profit from misgovernment may be reduced - in the latest constitution of the East India Company (EIC) it was reduced-to a singularly small amount" (CRG 462). As for its capacity, Mill maintains that a delegated body such as the EIC is "chiefly composed of persons who have acquired professional knowledge of this part of their country's concerns; who have been trained to it in the place itself, and have made its administration the main occupation of their lives"; additionally, their selection by competitive examination (discussed above) and their security of tenure as civil servants guarantee their competence and their "permanent interest in the success of their administration, and in the prosperity of the country which they administer" (CRG 462-64).

Mill contrasts this kind of delegated body with the alternative of direct rule by means of a minister immediately responsible to the British parliament. The problem with the latter arrangement, as Mill acidly remarks, is that an "English Cabinet Minister ... is thinking of English, not Indian politics" (CRG 461). Ministers, as members of Parliament, are subject to popular enthusiasms as well as the demands of powerful interest groups. An example of the first is the popular desire for the religious conversion of Indians, exemplified by "the demand now so general in England for having the Bible taught, at the option of pupils or of their parents, in the Government schools"; an example of the second is the sort of pressure applied to administrators by "individuals of the ruling people who resort to the foreign country to make their fortunes... [who] have the feelings inspired by absolute power, without its sense of responsibility" (CRG 457-58). Yielding to these pressures, as elected officials are likely to do, will not serve the developmental interests of the dependent population but rather subject them to religious proselytism and economic exploitation.
Several of Mill's claims about the capacity and motivation of colonial organs like the EIC have been challenged-at times with his own words. Suppose, however, that we grant his claims, at least insofar as they relate to the superiority of the EIC over direct Parliamentary rule. The following question then arises: why would a democratic people tie its own hands by means of a delegated administration? Mill's impassioned defense of the EIC in Considerations is made especially poignant by the fact that Parliament had already removed its authority in 1858, several years before Mill's book was published. Mill himself perhaps explains why this happened:

Such a thing as government of one people by another, does not and cannot exist. One people may keep another as a warren or preserve for its own use, a place to make money in, a human cattle farm to be worked for the [spiritual or pecuniary] profit of its own inhabitants. But if the good of the governed is the proper business of a government, it is utterly impossible that a people should directly attend to it. (CRG 456; emphasis added)

If this is true, then we should expect delegated administration to be the exception rather than the rule in imperial democracies, whose popular enthusiasms and powerful vested interests militate against precisely the calm self-restraint, disinterestedness, and professional expertise provided by the likes of EIC and the Mills. If this leaves us with the choice between an evangelical, rapacious democratic imperialism and the petty, repulsive native despotisms it would displace, then neither is the correct choice clear nor are our options particularly inspiring ones. The only thing that is certain is that we have traveled quite far from Mill's original vision, challenging yet hopeful, of an enlightened colonialism that seeks the individual and institutional development of a subject people and ultimately their political autonomy.

\section{Conclusion}

Far from Mill lacking a detailed narrative of the evolution of barbarous into civilized societies, he actually has a finely developed story to tell. Nor does he ignore the potential pitfalls of empire-notably abuse and exploitation-but rather folds his solutions to those problems into his larger theory of enlightened colonialism, as we saw in his application of it to India. The coherence, depth, moral seriousness, and self-critical quality of Mill's theory of enlightened despotism have to be understood and 
appreciated before an informed critique — such as this one-is possible.

Mill's deviation from his usual stalwart defense of representative democracy results from his belief that social, legal, and economic reform under nondemocratic regimes is not just a prelude to but a precondition of collective self-rule. Such reform would induce changes in the character, culture, and material conditions of a people that were favorable to the establishment of democracy. A people of slaves will never be transformed into a self-governing people unless they are led to acquire virtues not only of obedience and patient industry, but also of calculating intelligence, prudence, and self-control. But an enlightened despot must also cultivate additional democratic virtues, namely a spirit of nationality and a willingness to resist tyranny. Ironically, this sets the stage for the despot's own demise, as he must transform his rule from a "government of will to one of law," and extinguish his own governance in order to maintain legitimacy. This slow transition to democracy involves a step-by-step process of institutional reform (from slavery and serfdom to peasant proprietorship to political centralization and representative institutions) that induces a parallel process of character reform. At the conclusion of this process, the enlightened despot has managed to create not only a set of democratic institutions but also a citizenry virtuous enough to run them.

Understanding Mill's conception of the self-extinguishing despot and the role he plays in democratization enriches the existing debate about Mill and colonialism. The details of this account and its application to particular colonial contexts allow us to understand Mill better, to appreciate the unity of his thought, and to mount a more effective, informed critique of him than currently exists. Mill is neither a myopic liberal whose intellectual ken fails to extend beyond Western societies and their values nor a crude imperialist masquerading as a thoughtful liberal. Far from undermining his liberalism, his views on colonialism and underdeveloped societies are an essential part of his liberal understanding, and his exploration of the best ways for civilization to evolve demonstrates the comprehensive scope of his views even as it raises vital questions for us about the promise and the dangers of a democratic imperialism.

\section{Acknowledgments}

We thank Robert Adcock, Alex Zakaras, three anonymous reviewers, and the editors for their helpful comments.

\section{References}

Ball, Terence. 2000. "The Formation of Character: Mill's 'Ethology' Reconsidered.” Polity 33 (1): 25-48.

Bell, Duncan. 2010. "John Stuart Mill on Colonies." Political Theory 38 (1): 34-64.

Fuchs, Alan. 2001. "Autonomy, Slavery, and Mill's Critique of Paternalism." Ethical Theory and Moral Practice 4 (3): 231-51.

Himmelfarb, Gertrude. 1974. On Liberty and Liberalism: The Case of John Stuart Mill. New York: Knopf.

Holmes, Stephen. 2007. "Making Sense of Liberal Imperialism." In J.S. Mill's Political Thought: A Bicentennial Reassessment, ed. Nadia Urbinati and Alex Zakaras. Cambridge: Cambridge University Press, 319-46.

Kohn, Margaret, and Daniel I. O’Neill. 2006. “A Tale of Two Indias: Burke and Mill on Empire and Slavery in the West Indies and America." Political Theory 34 (2): 192-228.

Kurfirst, Robert. 1996. "J.S. Mill on Oriental Despotism, Including its British Variant.” Utilitas 8 (1): 73-87.

Mantena, Karuna. 2007. "Mill and the Imperial Predicament." In J.S. Mill's Political Thought: A Bicentennial Reassessment, ed. Nadia Urbinati and Alex Zakaras. Cambridge: Cambridge University Press, 298-318.

Mehta, Uday Singh. 1999. Liberalism and Empire: A Study in Nineteenth-Century British Liberal Thought. Chicago: University of Chicago Press.

Mill, John Stuart. 1972. The Collected Works of John Stuart Mill, Volume XVII - The Later Letters of John Stuart Mill 1849-1873 Part IV. Ed. Francis E. Mineka and Dwight N. Lindley. Toronto: University of Toronto Press.

Mill, John Stuart. 1977. The Collected Works of John Stuart Mill, Volume XVIII - Essays on Politics and Society Part I. Ed. John M. Robson. Toronto: University of Toronto Press.

Mill, John Stuart. 1985. The Collected Works of John Stuart Mill, Volume XX - Essays on French History and Historians. Ed. John M. Robson. Toronto: University of Toronto Press.

Mill, John Stuart. 1984. The Collected Works of John Stuart Mill, Volume XXI - Essays on Equality, Law and Education. Ed. John M. Robson. Toronto: University of Toronto Press.

Mill, John Stuart. 1990. The Collected Works of John Stuart Mill, Volume XXX - Writings on India. Ed. John M. Robson, Martin Moir, and Zawahir Moir. Toronto: University of Toronto Press.

Mill, John Stuart. 1991. On Liberty and Other Essays. Ed. John Gray. Oxford: Oxford University Press.

Mill, John Stuart. 1909. Principles of Political Economy: With Some of Their Applications to Social Philosophy. Ed. William James Ashley. London: Longmans, Green, and Company.

Miller, J. Joseph. 2005. "Chairing the Jamaica Committee: J. S. Mill and the Limits of Colonial Authority." In Utilitarianism and Empire, ed. Bart Schultz and Georgios Varouxakis. Lanham: Lexington Books, 155-78.

Montesquieu, Charles de Secondat, Baron, de. 1964. The Persian Letters. Trans. George R. Healy. Indianapolis, IN: Hackett.

Montesquieu, Charles de Secondat, Baron, de. 1989. The Spirit of the Laws. Trans. Anne M. Cohler, Basia C. Miller, and Harold S. Stone. Cambridge: Cambridge University Press.

Muthu, Sankar. 2003. Enlightenment against Empire. Princeton, NJ: Princeton University Press. 
North, Douglass C. 1990. Institutions, Institutional Change and Economic Performance. Cambridge: Cambridge University Press.

Pitts, Jennifer. 2005. A Turn to Empire. Princeton, NJ: Princeton University Press.

Reeves, Richard. 2007. John Stuart Mill: Victorian Firebrand. London: Atlantic Books.

Sullivan, Eileen P. 1983. "Liberalism and Imperialism: J. S. Mill's Defense of the British Empire." Journal of the History of Ideas 44 (4): 599-617.

Taylor, Robert S. 2006. "Democratic Transitions and the Progress of Absolutism in Kant's Political Thought." Journal of Politics 68 (3): 556-70.

Tunick, Mark. 2006. “Tolerant Imperialism: John Stuart Mill's Defense of British Rule in India.” The Review of Politics 68 (4): 586-611.
Urbinati, Nadia. 2007. "The Many Heads of the Hydra: J.S. Mill on Despotism." In J.S. Mill's Political Thought: A Bicentennial Reassessment, ed. Nadia Urbinati and Alex Zakaras. Cambridge: Cambridge University Press, 66-97.

Varouxakis, Georgios. 2002. Mill on Nationality. London: Routledge.

Yvonne Chiu is an Assistant Professor of Politics \& Public Administration at The University of Hong Kong, Hong Kong.

Robert S. Taylor is an Associate Professor of Political Science at The University of California, Davis, CA 95616. 